\section{Male's Knowledge and Awareness about AIDS/STDs in Rajshahi District of Bangladesh}

Mosiur Rahman

\begin{abstract}
As there is no cure to get rid of the unbearable sufferings from these diseases, prevention is the only solution to get rid of HIV/AIDS and STDs. Raising awareness among men about the long run effects of these diseases is one of the prime objectives of reproductive health programs currently executing in the world. Our study pays attention to get an idea of men's perception about these types of reproductive health problems. Findings reveal that about 87 percent men aware about HIV/AIDS and comparatively women were found same aware of AIDS. Only 54.8 percent men are found aware STIs, and more than 45 percent of the respondents have no knowledge of STIs. This indicates men's careless ness about these diseases. Mass media plays a great role in growing awareness about HIV/AIDS. Electronic, print media and interpersonal communication were the main sources of knowledge. About 30 and 40 percent men and women heard of AIDS from two sources respectively. It was found that majority of the male said uncontrolled sexual relation is the major reason of spreading AIDS. Although men's communication with their spouses can help in preventing AIDS but a large portion respondent don't talk to their spouses about preventing AIDS. Findings also elucidate that education, residence, religion, occupation, and mass media facility are the significant factors to influence AIDS knowledge among men.
\end{abstract}

Key words: HIV/AIDS, STDs, Logistic Regression Analysis, Bangladesh

\section{Introduction}

Bangladesh, with a population of 144,319,628 (July 2005 est.), had about 13,000 adults and children living with HIV infection at the end 2002, according to UNAIDS estimates. However, only 248 HIV cases have actually been reported. Significant underreporting of cases occurs because of the country's limited voluntary testing and counseling capacity and the social stigma, which leads to the fear of being identified and detected as HIV positive (Islam, N., T. Azim, C. Jenkins, et al. 2000). Although overall HIV prevalence is low, behavior patterns and extensive risk factors that facilitate the rapid spread of the infection are prevalent, making Bangladesh highly vulnerable to an HIV/AIDS epidemic (Kamal, M., E. Karim, et al., 1992). These risk factors are gender discrimination, Lack of basic sexual knowledge, lack of proper knowledge of sexually transmitted diseases (STDs/STI) lack of knowledge may be creating most problems for Bangladesh of HIV/AIDS epidemic in future. While knowledge of HIV is nearly universal among sex workers and their clients, it is extremely low among the general population especially among the male. In 1996-97 only 33 percent of men had ever heard of AIDS (MOHFW, Bangladesh, 1998). The last 15 years have witnessed increasing global recognition of the importance of men's involvement in sexual and reproductive health (SRH). Issues such as the AIDS epidemic have reinforced the urgency of encouraging men to take responsibility for their own sexual and reproductive health and that of their partners (Pulerwitz, J., Barker, G., Segundo, M., Nascimento, M., 2003.). Despite global recognition at the level of international agreements, many countries have not developed large-scale programs that reach out to men. As a result, many men are not aware of why they need to be involved in SRH, how they can be 
involved, and what services are available for them and their partners.

Men can help to abate the speedy rate of occurrences of these diseases by practicing safer sexual behavior (Sultan, P., K. Das, F. Zuberi, et al., 1999). The practices of social and cultural and religious norms can also lessen the intensity of these diseases. In many developing countries, particularly in African countries, spread of AIDS/HIV becomes a fatal disaster (Wawer MJ, Serwandda D, Musgrave SD et al., 1991) .In South Asian country like India four millions of people have infected from these diseases. In Bangladesh the condition is still far better than any other developing countries (HPSP, Bangladesh, 2005). There are various ways sexually transmitted infections AIDS are common among men and women in Bangladesh due to lack of proper knowledge. Until recently, little information has been found available on sexually transmitted infections (STIs) among men and women in Bangladesh. Prevention is the only solution to get rid of HIV/AIDS and STDs. Raising awareness among men about the long run effects of these diseases is one of the prime objectives of reproductive health programs currently executing in the world (Azim, T., J. Bogaerts, D. L. Yirrell, et al., 2001). Our study pays attention to get an idea of men's perception about these types of reproductive health problems.

\section{Methods and Materials}

The data were collected from a field survey conducted in the district of Rajshahi of Bangladesh. These data were collected from both, rural and urban areas of Rajshahi district. Information was collected of 500 ever-married male household head (male aged 15-64 years; as they are more responsive about the involvement in reproductive health) of which 250 women and 250 women are taken from urban and rural areas respectively by interview method. Respondents were selected by purposive sampling method. For rural areas we had selected three villages under Horogram Union, of Paba and for urban areas we have selected Rajpara Thana of Rajshahi Metropolitan City Corporation. Horogram union is located under the northern part of Rajshahi district. The toatal area is about 8.0 square kilometers. Its population is about 5070. Most of its population is employed in farming, agricultural labor, day labor etc. Data analytic methods envisaged in this paper are percentage distribution, graphical representation and logistic regression analysis.

\section{Knowledge about HIV/AIDS}

Although, Bangladesh is a low HIV prevalence country, the prevalence rate of HIV/AIDS in Bangladesh is on the rise. A vast section of people don't know what the impacts of these diseases are and how to avoid these (Sarkar, S., F. Durandin, A. A. Quader, et al. 1997). Different Govt. and nongovernment organizations (NGOs) are undertaking various awareness raising health programs to make consciousness among the people. In our sample data we observed that 87.0 percent men are conversant with HIV/AIDS the comparative figure in case of women is lower than that in case of men. The same result is found in figure- 1 . Radio and TV are broadcasting various programs to make more people conscious about AIDS/HIV. Newspapers are publishing features regarding these diseases.

Regarding the sources, from the table- 1 it is observed that electronic media like radio and TV are the leading sources of getting knowledge of HIV/AIDS as it is assumed. Nearly 41.4 percent men have got idea about HIV/AIDS from radio and 66.4 percent from TV. Newspapers (26.8 percent), health workers (33.0 percent) and friends (30.4 percent) are the major sources of getting information about these diseases. The comparative figures in case of women are showing low. 
Dhaulagiri Journal of Sociology and Anthropology Vol.2 | 257

Table 1: Knowledge and sources of information about HIV/AIDS

\begin{tabular}{|c|c|c|}
\hline $\begin{array}{c}\text { Knowledge of AIDS } \\
\text { /HIV }\end{array}$ & $\operatorname{Men}(N=500)$ & Women $(N=500)$ \\
\hline \\
\hline $\begin{array}{l}\text { HIV/AIDS } \\
\text { Yes }\end{array}$ & 870 & 866 \\
\hline $\begin{array}{l}\text { Yes } \\
\text { No }\end{array}$ & 13.0 & 13.4 \\
\hline \multicolumn{3}{|l|}{ Sources $\quad$ of } \\
\hline \multirow{2}{*}{\multicolumn{3}{|c|}{$\begin{array}{l}\text { HIV/AIDS } \\
\text { information }\end{array}$}} \\
\hline & & \\
\hline Radio & 41.4 & 43.2 \\
\hline & 66.4 & 65.4 \\
\hline Newspaper & 26.8 & 19.8 \\
\hline Poster & 31.8 & 25.4 \\
\hline Health workers & 33.0 & 40.4 \\
\hline Religious Institution & 27.6 & 2.4 \\
\hline Friends & 34.4 & 4.2 \\
\hline Work place & 16.6 & 3.4 \\
\hline \multirow{2}{*}{\multicolumn{3}{|c|}{$\begin{array}{lr}\text { Knowledge } & \text { of } \\
\text { AIDS } & \text { from }\end{array}$}} \\
\hline & & \\
\hline multiple sources & & \\
\hline No source & 12.2 & 13.8 \\
\hline 1 source & 14.4 & 13.6 \\
\hline 2 sources & 30.0 & 40.0 \\
\hline 3 sources & 16.4 & 22.4 \\
\hline .4 sources & 22.0 & 7.6 \\
\hline 5 and more sources & 5.0 & 2.6 \\
\hline
\end{tabular}

Source: Survey

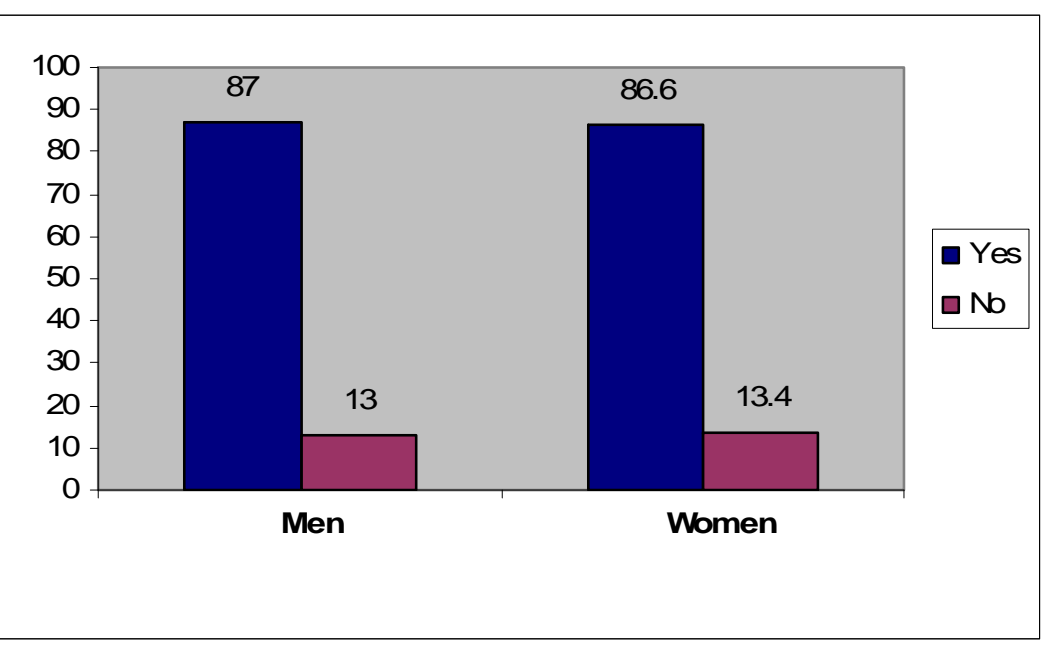

Figure-1 Comparative pictures of men and women's

\section{8 | Notes to Contributors}

\section{Knowledge about AIDS / HIV}

Again table-1 identifies how many sources from which men and women have known AIDS knowledge. It is found that about 12.2 percent of the men do not have knowledge on AIDS from different sources and the corresponding figure for women are 13.8 percent. Among the men who have ever heard AIDS, about 14.4 percent of them heard from only one source followed by 30.0 percent from two sources, 16.4 percent from three sources, 22.0 percent from four sources and only 5.0 percent from five or more sources. Among the women who have ever heard AIDS, about 13.6 percent of them heard from only one source followed by 40.0 percent from two sources, 22.4 percent from three sources, 7.6 percent from four sources and only 2.6 percent from five or more sources.

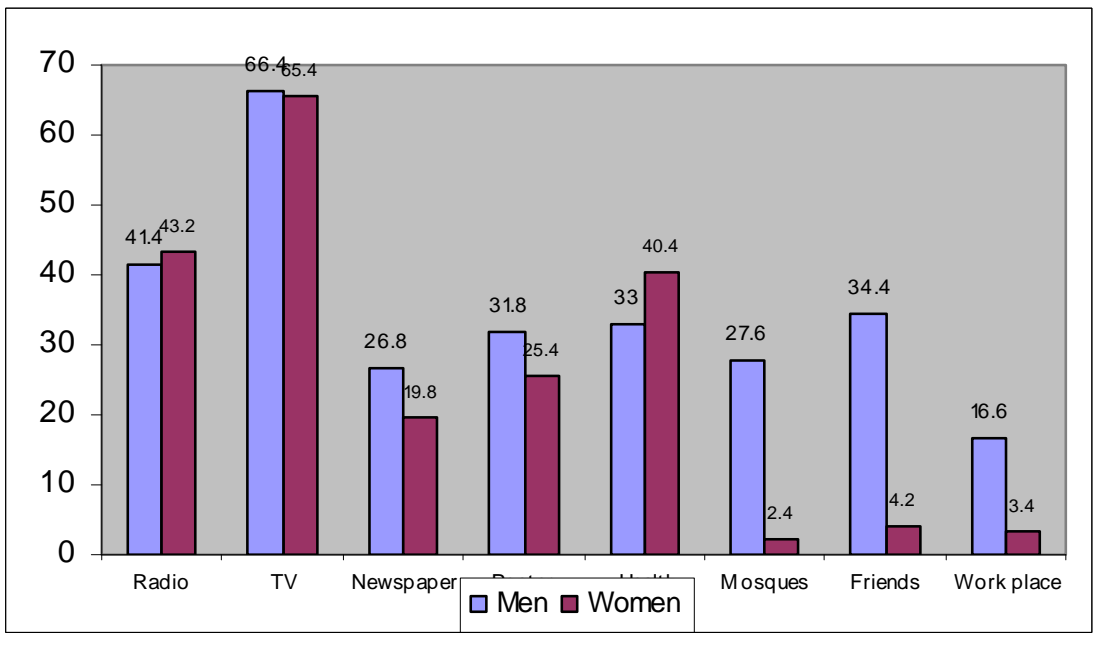

Figure-2 Knowledge about AIDS / HIV information from different sources among the men and women 


\section{Knowledge of Ways to Spread AIDS/HIV}

There is still misunderstanding about how HIV is transmitted from one person to another. (Sternberg, P. and J. Hubley. 2004). Epidemiological studies have shown that the only routes of AIDS transmission are through sexual intercourse, transmission of blood, injections, HIV-contaminated needles of syringes and transmission from an infected mother to her fetus or infant (Fisher, Andrew A. and James R. Foreit, 2002). To meet the targets and goals of AIDS prevention and control, there is strong need to assess the current levels of specific knowledge about AIDS transmission and prevention by urban-rural residence and other key socio-economic factors.

Emphasis is given on making knowledge how to avoid HIV/AIDS as there is no cure to get rid of the unbearable sufferings from these diseases. Some idea about the preventive measures to avoid HIV/AIDS is already explained. Men's indiscriminating sexual behavior is the prime cause of the occurrence of HIV/AIDS. So to bring change in developing healthy sexual relationship is essential for preventing these diseases. The table- 2 is giving the data regarding men's knowledge about the ways to spread HIV /AIDS. It is seen that uncontrolled sexual relationship with multiple partners is the way to spread HIV/AIDS is known by a large portion of men (62.0 percent). The ways like to spread by taking germ free blood and using same injection are the next that are frequently to known to men, 32.8 and 22.0 percent respectively. 32.6 percent men don't know how to avoid AIDS. This is relatively high figure.

\section{$260 \mid$ Notes to Contributors}

Table 2: Percentage distribution of men's knowledge about the way's to spread AIDS/HIV

\begin{tabular}{|l|c|}
\hline \multicolumn{1}{|c|}{ Ways to spread AIDS } & Men \\
\hline Uncontrolled sexual relation & 62.0 \\
Blood transfusion & 32.8 \\
Same injection & 22.0 \\
Sharing razors/blades & 9.0 \\
Kissing & 9.8 \\
Doesn't know specific way & 32.6 \\
Other & 9.2 \\
\hline
\end{tabular}

More interesting figure is found from the table- 3 that reveals men's complete ignorance about AIDS. Here the respondents are asked whether a healthy person can have AIDS or not. To answer this question 48.2 percent man said yes, which is a completely wrong idea. Men's communication with their spouses can help in preventing AIDS. In our country, people feel shyness to talk about AIDS. It is more true in case of couples. And our sample also tells this thing. 41.8 percent respondents don't talk to spouses about preventing AIDS.

Table-3: Percentage distribution of men who have heard of AIDS by perception of AIDS and communication with spouses about AIDS.

\begin{tabular}{|l|c|}
\hline \multicolumn{1}{|c|}{ Heard AIDS } & Men \\
\hline Can a healthy person have AIDS? & 48.2 \\
Yes & 19.6 \\
No & 32.6 \\
Don't know & \\
Talked to spouses about preventing & 58.2 \\
AIDS? & 41.8 \\
Yes & \\
No & \\
\hline
\end{tabular}

\section{Differential of AIDS Knowledge}

The results in table- 4 elucidates that about 87.6 percent of the respondents who were lived in the urban area, had heard of AIDS compared to 86.4 percent who were lived in rural area. 
From the table-4, we see that as the education level increases the knowledge of AIDS also rises. About 96.4 percent of the respondents who were completed primary education had heard of AIDS compared to 100.0 percent who were completed secondary and higher education. It is also observed that about 95.1 percent of the respondent's wife who were primary education completed, had heard of AIDS compared to 100.0 percent who were complete secondary and higher education.

Table-4: Percentage distribution of men who had heard of AIDS by some selected characteristics

\begin{tabular}{|c|c|c|}
\hline \multirow{2}{*}{ Characteristics } & \multicolumn{2}{|c|}{ Knowledge of AIDS among Men(N=500) } \\
\hline & Yes & No \\
\hline \multicolumn{2}{|l|}{ Tace of residence } & \\
\hline Rural & 86.4 & 13.6 \\
\hline Urban & 87.6 & 12.4 \\
\hline \multicolumn{3}{|l|}{$\begin{array}{l}\text { Respondent's } \\
\text { education }\end{array}$} \\
\hline No Education & 77.5 & 22.5 \\
\hline Primary & 80.3 & 19.7 \\
\hline Incomplete & 96.4 & 3.6 \\
\hline \multicolumn{3}{|l|}{ Primary Complete } \\
\hline Secondary and & & 0 \\
\hline \multirow{2}{*}{\multicolumn{3}{|c|}{ Wife's Education }} \\
\hline & 72.2 & 278 \\
\hline $\begin{array}{l}\text { INo Eaucation } \\
\text { Primary }\end{array}$ & 85.2 & 14.8 \\
\hline Incomplete & 95.1 & 4.9 \\
\hline Primary Complete & 100.0 & 0 \\
\hline \multicolumn{3}{|l|}{$\begin{array}{l}\text { Secondary and } \\
\text { Higher }\end{array}$} \\
\hline \multicolumn{3}{|l|}{ Respondent's } \\
\hline Occupation & & 6.1 \\
\hline Non-manual & 93.9 & 18.9 \\
\hline Manual & 81.1 & \\
\hline \multicolumn{3}{|l|}{ Religion } \\
\hline Islam & 86.4 & 13.6 \\
\hline \multicolumn{3}{|l|}{$\begin{array}{l}\text { Hindu and Other } \\
\text { Mass Media }\end{array}$} \\
\hline Yes & 89.7 & 10.3 \\
\hline No & 69.2 & 30.8 \\
\hline \multicolumn{3}{|l|}{ Current Method } \\
\hline Yes & 96.7 & 3.3 \\
\hline & 75.1 & 24.9 \\
\hline \multicolumn{3}{|l|}{ Permission about } \\
\hline $\begin{array}{l}\text { Outside Home } \\
\text { Give Permission }\end{array}$ & 100.0 & 0 \\
\hline No Permission & 83.2 & 16.8 \\
\hline
\end{tabular}

Table-4 also elucidates that about 93.9 percent of the respondents whose profession were non-manual (e.g., serviceman, businessman), had heard of AIDS compared to 81.1 percent whose profession were manual (e.g., day labor, farmer). It is also observed that non-Muslims are more aware of AIDS that than of Muslims (94.4 percent as against 86.4 percent). Regarding the sources from which the respondents heard about AIDS, the major sources of information on AIDS were found: radio, television, newspaper/magazine, religious personnel/poster, health workers, friends/elatives and work place. From the above table we see that about 89.7 percent of the respondents, who were related to mass media, had heard of AIDS compared to 69.2 percent who were not related to mass media. It is also observed that about 96.7 percent of the respondents who used current contraceptive method, had heard of AIDS as against 75.1 percent who were not used current contraceptive method. From the table- 4 we see that about 100.0 percent of the respondents who permit their wife to go outside the home for working purpose, had heard of AIDS compared to 83.2 percent whom were not permitted their wife to go outside the home for working purpose.

\section{Perception about STDs/ STIs}

Sexually transmitted infections (STIs) are a group of communicable diseases that are transmitted predominantly by sexual contact and caused by a wide range of bacterial, viral etc. agents. So, cleanliness is the essential measure to keep saves from STIs (Mian, M. A. H., M. A. Kabir, K. Begum 1996). Among the men knowledge about STDs is so poor. Various factors such as host factors, social factors and demographic factors are involved in the spread of STIs.

Men's sexual behaviors put women at risk. Sexually transmitted diseases (STDs) has been described as showing "bio-logical sexism", that is women are more susceptible physiologically to the viral and bacterial agents that cause 
them. As a result, men have transmitted infections to women more efficiently than women do to men (Holschneider, Silvia O.M. and C.S. Alexander. 2003). STDs are more difficult to detect in women, making accurate diagnosis harder. Women are less likely than men to receive timely treatment because they may have no symptoms at first, they are embarrassed, or they cannot get to a clinic. As a result sexually transmitted infections can progress to more serious medical conditions before woman seek treatment. Thus women suffer more longterm and painful consequences from STDs (Bloem, M., Z. Uddin, S. Sarkar, et al. 1998).

Table-5: Percentage distribution of respondent's by their knowledge of STIs (other than AIDS/HIV

\begin{tabular}{|l|c|}
\hline Knowledge of specific sign and symptoms & Men $(\boldsymbol{N}=\mathbf{5 0 0})$ \\
\hline Knowledge of STIs & 54.8 \\
No knowledge of STIs & 45.2 \\
Does not know any symptoms & 9.0 \\
Know only one symptom & 19.4 \\
Knows two symptoms & 18.4 \\
Knows three or more symptoms & 7.6 \\
\hline
\end{tabular}

Perception about sexually transmitted diseases mentioned above is essential, alongside the knowledge about AIDS, to lead a safer life. Ultimately it will keep the society more safe and healthy. But unfortunately, 45.2 percent men have no any idea about STDs as observed from the table-5. A small percentage of men know any symptom of STDs, 19.4 percent know only one symptom, 18.4 percent know any two symptoms and only 7.6 percent know three or more symptoms.

\section{Determinants of AIDS Knowledge}

Tables 6 show the logistic regression estimates of odds ratios for the effects of selected characteristics of married male on knowledge about AIDS respectively. The odds ratios are shown in place of regression coefficients for easy interpretation of the results. An odds ratio below 1.00 means a negative effect of an independent variable; an odds ratio above 1.00 means a positive effect. From table 6 it was found that as the educational level increases respondents knowledge about AIDS also increases. Secondary and higher educated respondents are two times more aware about AIDS than the respondents who are illiterate. The same result is found in case of respondent's wife education. Religious minded people, particularly of religion like Islam, favor to keep less knowledge about AIDS (Nkya WM, GiUcspie SH, Hawlett $\mathrm{W}$ et al. 1991). Our model also indicates the significance influence of religion. Non-Muslims are 1.220 times more likely to prefer to keep knowledge about AIDS as compare to men of Muslim religion. Respondents who are living in urban area are more about AIDS ac compared to their rural counterparts..

Mass media directly effects men's knowledge about AIDS in the country. People, particularly of illiterate, favor less knowledge about AIDS (McGinnis T, Bamba M. 1989.). Those Men who have mass media facility 2.728 times more likely prefer to keep knowledge about AIDS as compared to those respondents not having such facility. The respondents who use contraceptive methods currently are more likely to prefer to keep knowledge about AIDS as compared to those respondents who are not using contraceptive methods currently.

Table-6 Logistic Regression to explain AIDS knowledge among men

\begin{tabular}{|l|c|c|}
\hline \multirow{2}{*}{ Independent variable } & \multicolumn{2}{|c|}{ Dependent variable : Knowledge about AIDS } \\
\cline { 2 - 3 } & Coefficient $(\beta)$ & Odds ratio [Exp ( $\beta$ ] ] \\
\hline Education of Husband & & \\
No Education (Ref.) & $\ldots$ & 1.000 \\
Primary Incomplete & 7.105 & 1.491 \\
Primary Complete & 8.821 & $1.673^{*}$ \\
Secondary \& Higher & 9.588 & $2.000^{* *}$ \\
\hline Religion & & \\
Muslim (Ref) & $\ldots$ & 1.000 \\
Non-Muslim & 0.095 & $1.220^{* *}$ \\
\hline
\end{tabular}




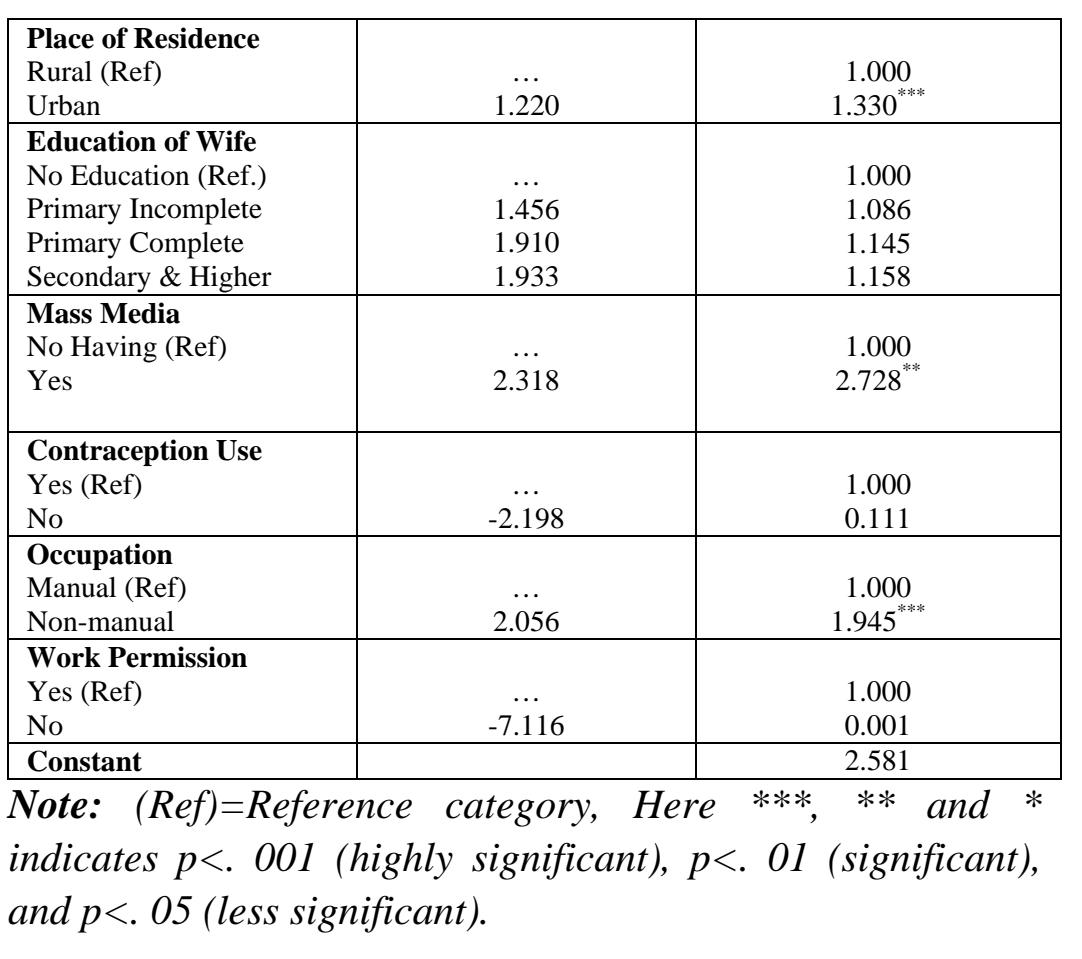

The respondents whose professions are non-manual (Service, Business etc.,) have more knowledge about AIDS as compared to those respondents whose professions are manual (Agriculture, Day labor etc.). The respondents who give permission to their wives to work outside home are more likely to prefer to keep knowledge about AIDS as compared to those respondents who are not give permission to their wives to work outside home.

\section{Conclusion}

The analysis found that 87 percent men have heard of AIDS and comparatively women were found same aware of AIDS. Regarding the sources from which the respondents come to know about AIDS, 30 percent men heard of AIDS from two sources and the corresponding figure for respondent's wife is 40 percent. Only 54.8 percent men are found aware of STIs, and more than 45 percent of the respondents have no knowledge of STIs, this indicates men's careless ness about these diseases. Mass media plays a great role in growing awareness about HIV/AIDS. Among all the sources newspaper was the most influential source, from which about 66.4 percent male and 65.4 percent female have known about AIDS/HIV. The study also examined the possible ways to spread AIDS. Uncontrolled sexual relation is the main cause answer by the respondents who knew at least one way of spread AIDS. Men's communication with their spouses can help in preventing AIDS. In our country, people feel shyness to talk about AIDS. It is more true in case of couples. And our sample also tells this thing. 41.8 percent respondents don't talk to spouses about preventing AIDS. From the logistic regression, we observed that five out of eight variables are significant to explain AIDS knowledge of men. Respondents residing in urban areas, having secondary and higher education, having mass media facilitates are more conscious about AIDS It was also found that non-Muslim respondents and the respondents who are non-manual workers are more aware about knowledge of AIDS than their Muslim counterparts

The overall scenario of men's knowledge and awareness of AIDS/STDs is not satisfactory. Still much work has to be done in this arena to cope with the problems of our country. In the light of the above discussions the following recommendations are made:

- Our study found that education is positively associated with male's knowledge about AIDS. 


\section{Notes to Contributors}

Literacy rate should have to be increased to reach the target.

- STI/HIV prevention programmes should target men within their specific reproductive age groups, with messages expressed in such a way so as to ensure that male are made aware of the need for lifelong protection for themselves and their partners. Such programmes should be developed specifically for youths attending schools, men at the workplace.

- Male participation in preventing sexually transmitted diseases, including HIV, is crucial. Governments, nongovernmental organizations (NGOs), donors' agencies and relevant stakeholders should ensure availability, accessibility and sustained advocacy for use of condoms for dual protection against unwanted pregnancy and STIs/HIV

- Equal relationships between men and women in matters of sexual relations and reproduction, including full respect for the integrity of the person, require mutual respect, consent and shared responsibility for sexual behavior and its consequences

- The mass media should be used more frequently and more effectively. Radio and TV can be used for broadcasting and telecasting special awareness programmes taking into consideration the peak listening hours, viewing hours and day of the week. Newspapers can also play a major role by putting only one common advertisement daily on the importance of prevention of AIDS

\section{Reference}

Azim, T., J. Bogaerts, D. L. Yirrell, et al. (2001). Injecting Drug Users in Bangladesh: Prevalence of Syphilis, Hepatitis and HIV and HIV Subtypes. $6^{\text {th }}$ International Congress on AIDS in Asia and the Pacific, Melbourne, Australia, 10/5-10, Session Su1616.

Bloem, M., Z. Uddin, S. Sarkar, et al. (1998). The Street Walkers of Dhaka City: STD/HIV Risk among Street Based Sex Workers of Dhaka City. 12 ${ }^{\text {th }}$ World AIDS Conference, Geneva, 6/28 - 7/3, Abstract 43347, Factors. INSERM: 31-42.

Frank O. (1983). Infertility in Sub-Saharan Africa. Centre for Policy Studies working paper. New York: The Population Council.

Fisher, Andrew A. and James R. Foreit. (2002). Designing HIV/AIDS Intervention Studies: An Operations Research Handbook. Washington DC: Population Council.

Guest I. (1978). Infertility in Africa. People 5(1): 23-34.

Islam, N., T. Azim, C. Jenkins, et al.(2000). Report on the SeroSurveillance and Behavioural Surveillance on STD and AIDS in Bangladesh 1998-1999. AIDS and STD Control Programme, Ministry of Health and Family Welfare, Government of the People's Republic of Bangladesh, June, report.

Kamal, M., E. Karim, et al. (1992). Status of AIDS/HIV Infection: Bangladesh Institute of Epidemiology, Disease Control and Research, report.

Mian, M. A. H., M. A. Kabir, K. Begum (1996). Comparative Analysis of Point Prevalence of the Different Types of STD in ICSW and FCSW. XI International Conference on AIDS, Vancouver, 7/7-14, Abstract Pub.B.1048. 


\section{Dhaulagiri Journal of Sociology and Anthropology Vol.2 | 269}

McGinn T, Bamba M. (1989). Male Knowledge, Use and Attitudes Regarding Family planning in Burkina Faso. International Family Planning Perspectives 15(2): 87.

Ministry of Health and Family Welfare (MOHFW, Bangladesh, 1998). Health and Population SectorProgramme 1998-2003. Programme Implementation Plan, Part I. Dhaka, Bangladesh: MOHFW.

Nkya WM, GiUcspie SH, Hawlett W et al. (1991). Sexually Transmitted Diseases in Prostitutes in Moshi and Arusha, Northern Tanzania. International Journal of STD and AIDS 2(6): 432-5.

Pulerwitz, J., Barker, G., Segundo, M., Nascimento, M. (2003). Promoting more Gender-Equitable norms and Behaviors among Young Men as an HIV/AIDS Prevention strategy. Horizons Final Report. Washington, DC:Population Council.

Sultan, P., K. Das, F. Zuberi, et al. (1999). Seroprevalence of HIV, HTLV, Syphilis and Hepatitis in Tuberculosis Patients in Chittagong, Bangladesh. $5^{\text {th }}$ International Congress on AIDS in Asia and the Pacific, Kuala Lumpur, Malaysia, 10/20-27, Abstract MAB08-06.

Sarkar, S., F. Durandin, A. A. Quader, et al. (1997). Estimation of Number of Street Based Female Commerical Sex Workers (CSWS) and Their HIV Situation in the City of Dhaka. $4^{\text {th }}$ International Congress on AIDS in Asia and the Pacific, Manila, Philippines, 10/25-29, Poster AP071.

Sternberg, P. and J. Hubley. (2004). Evaluating Men's Involvement as a Strategy in Sexual and Reproductive Health Promotion. Health Promotion International 19(3): 389-96

Health and Population Sector Program (HPSP, Bangladesh, 2005). Bangladesh HPSP Annual ProgramReview (3-24 April 2005),

\section{0 | Notes to Contributors}

Independent Technical Report. Dhaka: Health and Population Sector Program.

Holschneider, Silvia O.M. and C.S. Alexander. (2003). Social and Psychological Influences on HIV Preventive Behaviors of youth in Haiti. Journal of Adolescent Health 33(1): 31-40.

Wawer MJ, Serwandda D, Musgrave SD et al. (1991). Dynamics of the Spread of HTV-l Infection in a Rural District of Uganda. British Medical Journal 303: 1303-6. 


\section{Notes to Contributors}

Dhaulagiri Journal of Sociology and Anthropology, MMC, Baglung, is a compilation of articles, original research reports, review articles, book reviews, dissertation abstracts, professional announcements, and other information of interest in the areas of sociology and anthropology of Nepal and other regions. Articles may be of both Nepalese and foreign scholars. Research articles on current issues in Sociology and anthropology are mostly preferred.

Articles should be in English. It should not exceed 4000-6000 words. The title of the paper should be 14 points bold, subtopic 12 point bold and normal text 12 point in Times New Roman (Font). Authors must take full responsibility for the originality, contents, and opinions expressed in their articles, must be suitably acknowledged. Spelling should follow that of the Oxford English Dictionary or Webster's New Word College Dictionary. Words in other language than English should be in italics. The Contributors are requested to maintain consistency throughout their articles.

The text should refer to notes numbered consecutively throughout the article, publication and biographical references should be cited in the text by the author's last name, date of publication and page number, e.g. (Khattri 2003:54) or if the author's name is mentioned in the text, by the date and page reference only (2003:54). Entries in the references should be in alphabetical and chronological order: name of author(s)-surname first, date, title, name of periodical, volume number (Arabic numerals to be used throughout), place of publication (and name of the publisher for a book). Examples of Reference format are as follows:
Mishra, Chaitanya (1984). Social Research in Nepal: A Critique and A Proposal. Contribution to Nepalese Studies. Vol. 11 (2), 1-11

Sherestha, Bal Gopal (2002). The Ritual Composition of Sankhu: The Socio-Religious Anthropology of Newar Town in Nepal. Unpublished Ph.D. Thesis. Leiden University.

Tiwari, Sudarsan Raj (2001). The Ancient Settlement of the Kathmandu Valley. Kathmandu: Center for Nepal and Asian Studies, Tribhuvan University.

Contributors are requested to send, if possible, their materials on computer Compact Disk (CD) using IBM compatible word processing program. They are requested to submit article online, abstract of about 200 words, keywords are necessary to be included. They, however, are requested to send a copy of the manuscript separately as a hard copy. The text, notes, and references should be typed double-spaced. The title of the paper, authors name, affiliations, and complete address should appear on the first pages. All correspondences related to editorial and subscription should be addressed to:

The Chairperson

Or

Editor-In-Chief

Department of Sociology/Anthropology

Mahendra Multiple Campus, Baglung.

E-mail: mankhattri@yahoo.com 